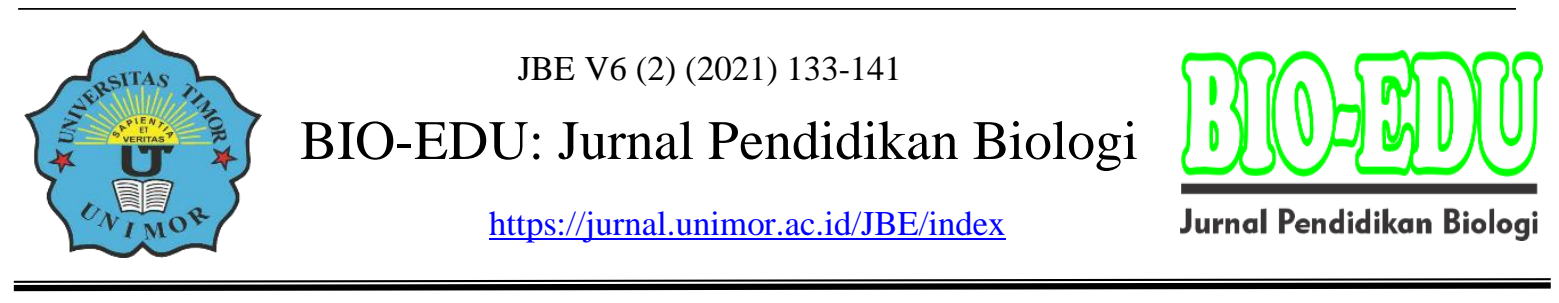

\title{
Media Interaktif $e$-Modul Materi Virus Sebagai Penunjang Pembelajaran Daring di MAN 3 Jombang
}

\author{
Suci Prihatiningtyas ${ }^{1}$, M. Wildan Tijanuddarori², Ospa Pea Yuanita Meishanti ${ }^{3}$, \\ Primadya Anantyarta ${ }^{4}$ \\ ${ }^{1}$ Program Studi Pendidikan Fisika, Universitas KH. A. Wahab Hasbullah \\ ${ }^{2,3}$ Program Studi Pendidikan Biologi, Universitas KH. A. Wahab Hasbullah \\ ${ }^{4}$ Program Studi Pendidikan Biologi, IKIP Budi Utomo Malang \\ suciningtyas@unwaha.ac.id
}

DOI: https://doi.org/10.32938/jbe.v6i2.1097

\begin{abstract}
Abstrak
Pandemi covid-19 berdampak pada pembelajaran di sekolah. Hal ini juga terjadi di MAN 3 Jombang, pembelajaran yang dilakukan adalah pembelajaran daring. Berdasarkan analisis kebutuhan, pembelajaran daring membuat peserta didik kurang memahami materi yang disampaikan karena guru hanya memberikan materi melalui ppt dan media yang digunakan hanya buku pegangan siswa dan LKS saja. Tujuan dari penelitian ini adalah mengembangkan media pembelajaran berupa $e$-modul materi virus sebagai pendukung pembelajaran daring di MAN 3 Jombang dengan melihat. Rumusan masalah dalam penelitian ini Bagaimana desain dan kelayakan media pembelajaran $e$-modul untuk pembelajaran biologi materi virus serta bagaimana respon siswa setelah menggunakan $e$-modul. Instrumen pengumpulan data berupa lembar validasi ahli media, lembar validasi ahli materi dan angket respon siswa. Berdasarkan penelitian yang dilakukan maka dapat disimpulkan $e$-modul materi virus yang dikembangkan layak digunakan dengan revisi dengan presentase rata-rata yang diberikan oleh validator sebesar $80,43 \%$.Keseluruhan peserta didik memberikan respon sangat baik dengan presentase rata-rata sebesar $88,83 \%$ terhadap $e$-modul materi virus yang dikembangkan dapat mendukung pembelajaran secara daring.
\end{abstract}

Kata Kunci: $e$-modul, virus, media interaktif, pembelajaran daring, flip pdf professional

\begin{abstract}
The Covid-19 pandemic has an impact on learning in schools. This also happens in MAN 3 Jombang, the learning that is done is online learning. Based on the needs analysis, online learning makes students less understanding of the material presented because the teacher only provides material through ppt and the media used is only student handbooks and student worksheets. The purpose of this research is to develop learning media in the form of emodule virus material to support online learning in MAN 3 Jombang by observing. Formulation of the problem in this study How to design and feasibility of e-module learning media for learning biology material on viruses. The data collection instruments were in the form of a media expert validation sheet, a material expert validation sheet and a student response questionnaire. Based on the research conducted, it can be concluded that the e-module virus material developed is feasible for use with revisions with an average percentage given by the validator of $80.43 \%$. Overall students responded very well with an average percentage of $88.83 \%$ against the e-module virus material that was developed to support online learning.
\end{abstract}

Keywords: e-module, virus, interactive media, online learning, flippdfprofessional 


\section{PENDAHULUAN}

Covid 19 saat ini telah menjajah negara Indonesia, dimana penyebaran penyakit tersebut sangat cepat. Bukan hanya di Indonesia, bahkan di penjuru dunia saat ini sedang mengalami krisis kesehatan. Awalnya penyebaran covid 19 sangat berdampak pada kegiatan ekonomi yang mulai lesu, tidak hanya itu dilansir dari berita harian Kompasiana (2020) pemerintah di beberapa daerah juga membuat kebijakan penutupan jalan hingga pembatasan wilayah untuk warga yang ingin keluar masuk dalam suatu daerah yang juga disebut lockdown. Namun saat ini dampak dari wabah tersebut juga dirasakan oleh dunia pendidikan (Handarini dkk, 2020). Pembelajaran yang biasanya dilaksanakan dengan menggunakan tatap muka (offline), sekarang menjadi pembelajaran secara dalam jaringan atau dikenal dengan daring (online). Pembelajaran daring adalah sistem pembelajaran dengan memanfaatkan jaringan internet untuk melakukan hubungan pembelajaran (Sadikin et al., 2020). Pelaksanaan pembelajaran daring didasarkan Surat Edaran Kemendikbud Nomor 2 Tahun 2020 dan Nomor 3 Tahun 2020 tentang pembelajaran daring dan berkerja dari rumah dengan tujuan memutuskan penyebaran COVID-19(Sutriyani, 2020).

Berdasarkan analisis situasi yang dilakukan di MAN 3 Jombang, selama masa pendemi Covid 19 pembelajaran yang dilakukan juga dilakukan secara daring. Pembelajaran dilakukan berbantuan flatform pembelajaran, seperti zoom meeting, google meeting, google classroom, dan whatshapp. Hasil observasi menunjukkan bahwa $83 \%$ pembelajaran daring membuat siswa tidak paham materi yang disampaikan, $76 \%$ merasa bosan dan jenuh sehingga tak jarang dari mereka mematikan kamera dan ditinggal tidur, $82 \%$ kendala sinyal dan biaya kuota yang mahal membuat materi yang disampaikan tidak dapat sepenuhnya diterima oleh siswa, $85 \%$ guru hanya memberikan materi berupa ppt dan memberikan latihan soal tanpa tau kemampuan siswa sudah memahami atau belum, 67\% mengatakan bahwa media yang digunakan hanya buku pegangan siswa dan LKS saja. Hal ini didukung oleh penelitian Alfiah, dkk (2020) menunjukan bahwa pembelajaran di rumah mengalami masalah dalam penggunaan teknologi dan terkendalanya koneksi internet dalam proses belajar mengajar.Penelitian Setyorini (2020) dalam Santoso (2020) menunjukan bahwa siswa, guru, dan orang tua mengalami problematika dalam kegiatan belajar mengajar seperti kurangnya penguasaan teknologi, biaya internet yang mahal, dan adanya jam tambahan orang tua untuk mendampingi anak belajar.

Berbagai upaya peningkatan kualitas pembelajaran terus dilakukan, diantaranya melalui pengembangan bahan ajar, dan media pembelajaran serta pemanfaatan Teknologi Informasi dan Komunikasi (TIK) dalam pembelajaran biologi. Bahan ajar adalah segala bentuk bahan yang digunakan untuk membantu guru/instruktor dalam melaksanakan kegiatan belajar mengajar di kelas (Nurdyansyah, 2018). Bahan ajar dapat berupa bahan ajar cetak maupun non cetak. Contoh bahan ajar antara lain buku, modul, media interaktif, Elektronik Modul (Emodul), dll. Modul ialah bahan belajar yang dirancang secara sistematis berdasarkan kurikulum tertentu dan dikemas dalam bentuk satuan pembelajaran terkecil dan memungkinkan dipelajari secara mandiri dalam satuan waktu tertentu (Solihudin, 2018).

Modul elektronik atau dikenal dengan $e$-modul adalah seperangkat media pengajaran digital atau non cetak yang disusun secara sistematis yang digunakan untuk keperluan belajar mandiri,sehingga menuntut peserta didik untuk belajar memecahkan masalah dengan caranya sendiri (Prihatiningtyas, 2020). Elektronik Modul dapat diisi materi dalam bentuk pdf, video serta animasi yang mampu membuat user belajar secara 
aktif. Keberadaan e-modul dapat membuat siswa belajar secara mandiri karena dilengkapi petunjuk dalam belajar, selain bentuknya menarik dan dapat diakses menggunakan gadget. Pendapat serupa dikatakan oleh Laili dkk (2019) bahwa Kemajuan teknologi juga telah memungkinkan e-modul ditampilkan melalui smartphone.

Berdasarkan kajian di atas, rumusan masalah dalam penelitian ini adalah (1) Bagaimana desain media pembelajaran $e$-modul untuk sebagai pendukung pembelajaran daring pelajaran biologi materi virus? (2) Bagaimana kelayakan media pembelajaran emodul untuk pembelajaran biologi materi virus?. Tujuan dari penelitian ini untuk mengetahui desain $e$-modul materi virus dan mengetahui kelayakan media $e$-modul materi virus sebagai pendukung pembelajaran daring di MAN 3 Jombang.Harapannya dengan pengembangan $e$-modul ini agar pengembangan ini, dapat memicu para pendidik untuk lebih kreatif lagi dalam membuat bahan ajar yang beragam, sehingga dapat terciptanya suasana yang tidak menjenuhkan atau menciptakan suasana pembelajaran yang berbeda agar tidak membosankan (Wulandari, 2020)

\section{METODE}

Penelitian ini menggunakan metode penelitian dan pengembangan (Research and Development / R\&D). Model pengembangan yang digunakan adalah ADDIE \{ Analysis (Analisis), Design (Perancangan), Development (Pengembangan), Implementation, dan Evaluation (Evaluasi) \}. Subjek ujicoba adalah ahli materi, ahli media, dan peserta didik. Uji coba dilaksanakan di kelas X MAN 3 Jombang dengan jumlah 50 peserta didik yang memberikan respon penilaian terhadap $e$-modul ini yang telah disajikan melalui angket menggunakan googleform. Instrumen pengumpulan data berupa lembar validasi ahli media, lembar validasi ahli materi dan angket respon siswa. Teknik analisis data:

1. Uji kelayakan $e$-modul

Angket yang digunakan dalam analisis data kuantitatif ini menggunakan skala Likert. Adapun kriteria skor dengan skala Likert yang dijelaskan oleh (Prihatiningtyas et al., 2020) dapat dilihat pada Tabel 1

Tabel 1. Pedoman Penilaian Kategori Skala Likert

\begin{tabular}{ll}
\hline Penilaian & Nilai \\
\hline Sangat Valid/layak & 4 \\
\hline Valid/layak & 3 \\
\hline Kurang Valid/layak & 2 \\
\hline Tidak Valid/layak & 1 \\
\hline
\end{tabular}

Data yang terkumpul dianalisis dengan cara dijumlahkan, dibandingkan dengan jumlah yang diharapkan sehingga diperoleh presentase, atau dapat ditulis dengan rumus sebagai berikut:

Presentase kelayakan $(\%)=\frac{\text { skor } \text { yang diobservasi }}{\text { skor } \text { yang diharapkan }} \times 100 \%$

Setelah data terkumpul dan dianalisi maka selanjutnya dikualifikasi tingkat kelayakannya dengan menggunakan konversi tingkat kelayakan seperti Tabel 2. 
Tabel 2. Konversi Tingkat Kelayakan

\begin{tabular}{lll}
\hline Tingkat Ketercapaian & Kualifikasi & Keterangan \\
\hline $90 \%-100 \%$ & Sangat Layak & Tidak perlu revisi \\
\hline $75 \%-89 \%$ & Layak & Direvisi \\
\hline $65 \%-74 \%$ & Cukup Layak & Direvisi \\
\hline $55 \%-64 \%$ & Kurang Layak & Direvisi \\
\hline $0 \%-54 \%$ & Tidak Layak & Direvisi \\
\hline
\end{tabular}

2. Analisis Respon Siswa

Data hasil respons yang diberikan kepadapeserta didik dianalisis dengan menggunakan statistik deskriptif dengan persentase. Persentase respons peserta didik dihitung dengan rumus:

$$
\% \text { respon }=\frac{\text { skor respon yang diperoleh }}{\text { skor maksimum respon }} \times 100 \%
$$

Analisis respon peserta didik, setelah persentase didapat kemudian mencocokan kedalam kriteria pedoman penilaian yang telah dibuat sesuai dengan Tabel 3

Tabel 3. Kriteria Respon Siswa

\begin{tabular}{llll}
\hline Persentase & Nilai huruf & Bobot & Predikat \\
\hline $86 \%-100 \%$ & A & 4 & Sangat Baik \\
\hline $76 \%-85 \%$ & B & 3 & Baik \\
\hline $60 \%-75 \%$ & C & 2 & Cukup Baik \\
\hline $55 \%-59 \%$ & D & 1 & Kurang Baik \\
\hline $0 \%-54 \%$ & E & 0 & Tidak Baik \\
\hline
\end{tabular}

\section{HASIL DAN PEMBAHASAN}

1. Analyze (Analisis).

Pada tahap analisis terdapat 3 hal yang harus dianalisis, meliputi analisis kebutuhan, analisis kurikulum dan analisis materi. Analisis kebutuhan merupakan tahap awal yang harus dilakukan karena pada tahap ini bertujuan untuk menetapkan masalah dasar yang dihadapi dengan pengembangan e-modul. 
Hal yang dibutuhkan dalam mengembangkan $e$-modul yaitu belum adanya $e$-modul di MAN 3 Jombang yang berisi tentang materi, gambar, video yang dapat diakses melalui personal computer maupun smartphone. Analisis Kurikulum menyesuaikan kurikulum 2013 revisi 2018. Analisis materi yang dilakukan peneliti melalui identifikasi materi yang akan diajarkan. Materi yang akan diajarkan adalah virus yang terdiri dari sub-sub materi. Sub-sub materinya adalah Sejarah Penemuan Virus, Ciri-ciri virus, Struktur Virus, Bentuk Virus, Reproduksi Virus, Klasifikasi Virus, dan Peran Virus dalam kehidupan.

2. Design (Desain)

Tahap desain ini meliputi penyusunan draf $e$-modul dan pengaplikasiannya ke dalam flipbook PDF professional. Tahapan dalam penyusunan desain media pembelajaran ini, menyesuaikan kompetensi inti, kompetensi dasar serta indikator. Mengumpulkan bahan-bahan pendukung termasuk buku-buku, filefile pendukung untuk membuat materi virus dalam $e$-modul ini. Desain $e$-modul materi virus dapat dibagi menjadi tiga bagian yaitu bagian depan meliputi halaman sampul, daftar isi, pendahuluan, kompetensi inti, kompetensi dasar, tujuan pembelajaran, peta konsep dilihat pada Gambar 1.
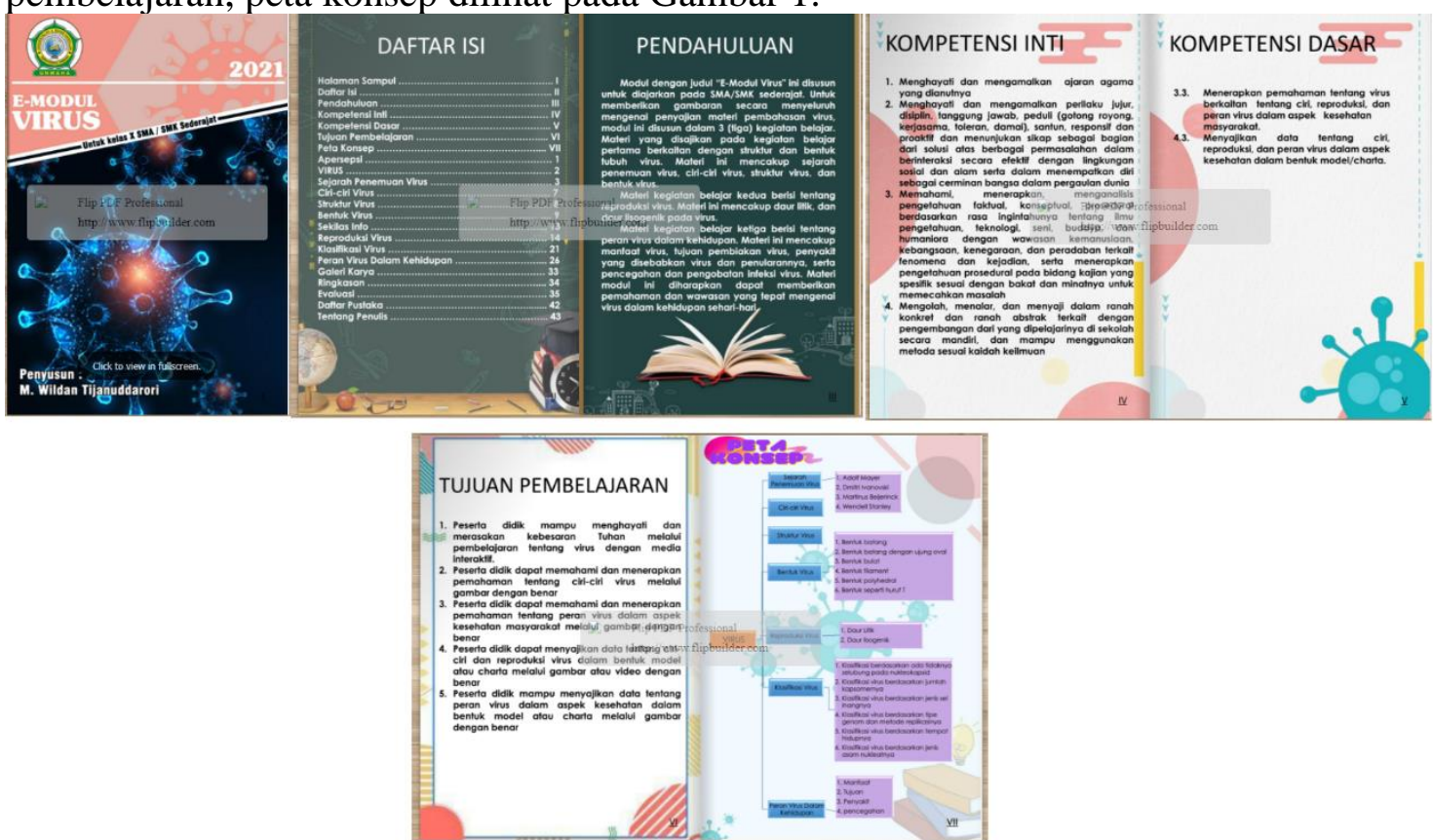

Gambar 1. Bagian depan e-modul meliputi halaman sampul, daftar isi, pendahuluan, kompetensi inti, kompetensi dasar, tujuan pembelajaran, peta konsep

Bagian kedua merupakan isi dari $e$-modul meliputi materi virus, sekilas info dan galeri karya seperti yang ditunjukkan Gambar 2. Bagian isi berisi materi, gambar dan video yang berhubungan dengan materi. 


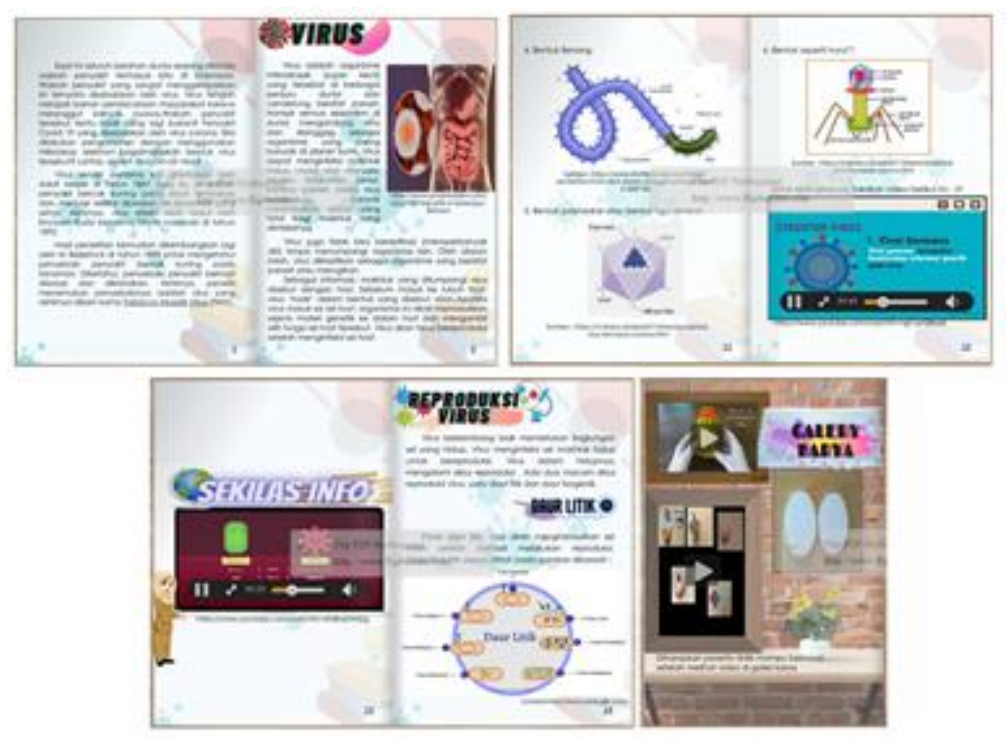

Gambar 2. Bagian isi $e$-modul materi virus, sekilas info dan galeri karya

Bagian ketiga merupakan penutup $e$-modul yang berisi ringkasan, evaluasi, daftar pustaka dan tentang penulis yang dapat dilihat pada Gambar 3.

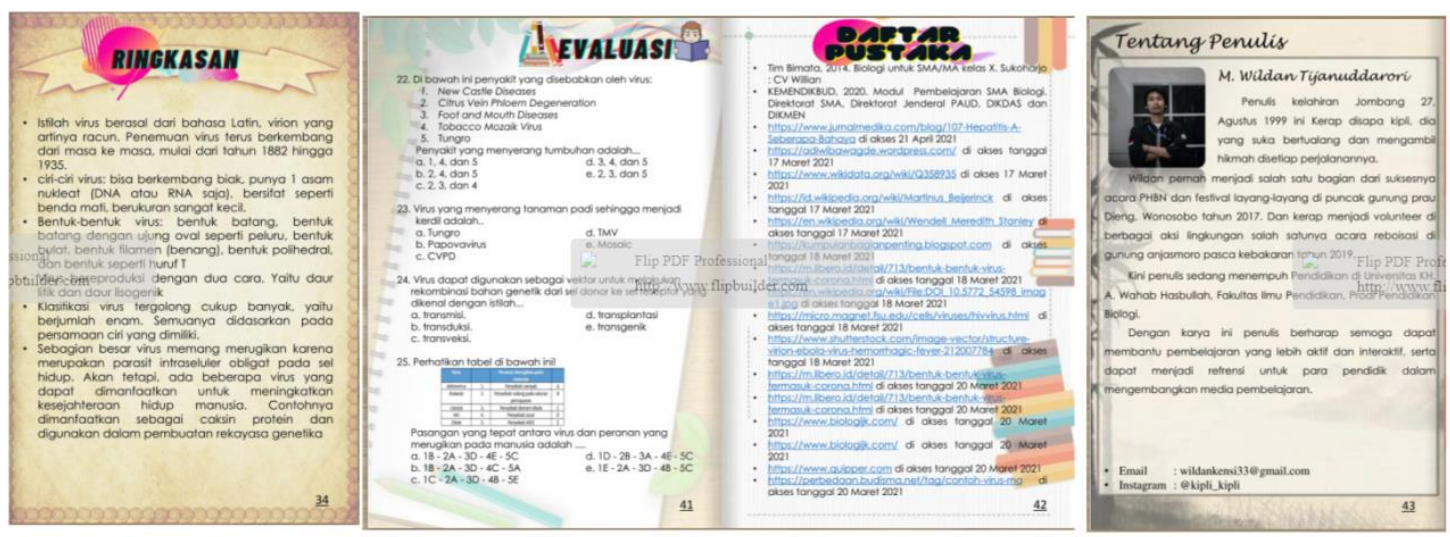

Gambar 3. Bagian penutup $e$-modul yang berisi ringkasan, evaluasi, daftar pustaka dan tentang penulis

Desain secara lengkap dapat dilihat dam website:https://online.flipbuilder.com/wsgz/frvd/

3. Development (pengembangan)

Pada tahap Development, $e$-modul materi virus yang sudah dikembangkan akan divalidasi oleh para ahli untuk mengetahui kelayakan berdasarkan penilaian ahli materi yang berkompeten di bidang pendidikan biologi dan ahli media yang berkompeten dalam bidang media pembelajaran interaktif. Hasil validasi dari validator disajikan pada Gambar 4. 


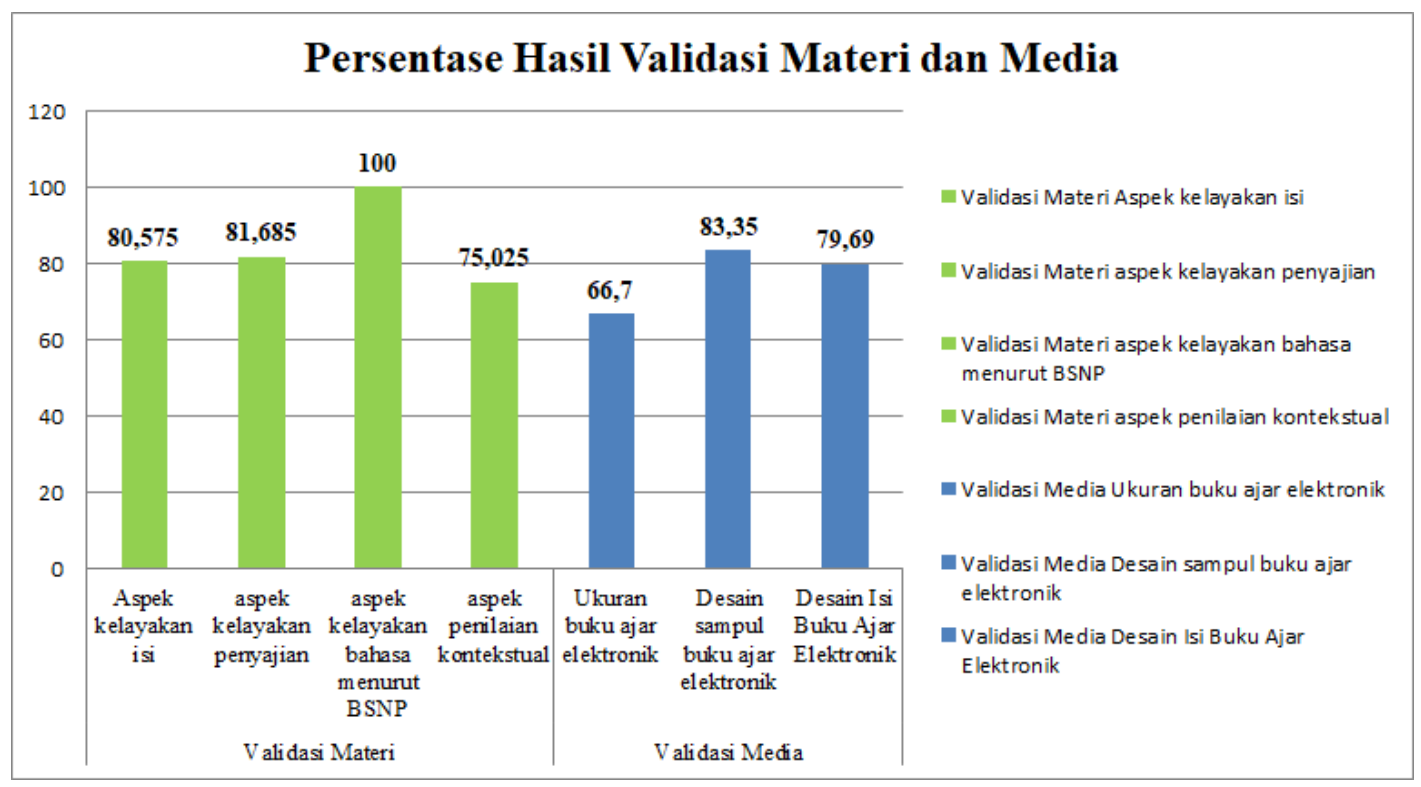

Gambar 4. Persentase hasil validasi materi dan media

Berdasarkan Gambar 4 bahwa aspek penilaian pada ahli materi ada empat yaitu aspek kelayakan isi, aspek kelayakan penyajian, aspek kelayakan bahasa menurut BSNP dan aspek penilaian kontekstual dengan persentase rata-rata keseluruhanaspek 84,3\% dengan kualifikasi layak. Indikator penilaian media ada 3 yaitu ukuran $e$-modul, desain sampul e-modul dan desain isi $e$-modul dengan persentase rata-rata keseluruhan indikator penilaian sebesar 76,56\% dengan kualifikasi layak. Hasil analisis validasi ahli materi dan ahli media dapat dikatakan bahwa secara keseluruhan e-book materi virus yang dikembangan layak untuk digunakan dalam pembelajaran materi virus pada kelas X MAN 3 Jombang dengan persentase nilai validasi ahli materi dan ahli media sebesar 80,43\%.Hasil penelitian ini relevan dengan penelitian Seruni (2019) yang berjudul Pengembangan Modul Elektronik (E-Modul) Biokimia Pada Materi Metabolisme Lipid Menggunakan Flip PDF Professional yang menghasilkan produk dengan kriteria sangat baik.

\section{Implementation (implementasi)}

Tahap implementasi dilakukan dengan caramemberikan angket respon peserta didik setelah menggunakan $e$-modul materi virus. Implementasi dilakukan pada peserta didik kelas XMAN 3 Jombang sebanyak 50 orang. Implementasi untuk mengetahui respon penggunaan $e$-modul materi virusdinilai menggunakan google form.

\section{Evaluation (Evaluasi)}

Evaluasi dilakukan untuk melihat apakah $e$-modul materi virussesuai harapan awal atau tidak. Evaluasi diperoleh dari hasil respon peserta didik setelah menggunakan media pembelajaran $e$-modul materi virus.Respon peserta didik diperoleh dari hasil pengisian angket respon setelah membaca respon peserta didik secara garis besar dapat dibuat grafik seperti yang ditunjukkan pada Gambar 5. 


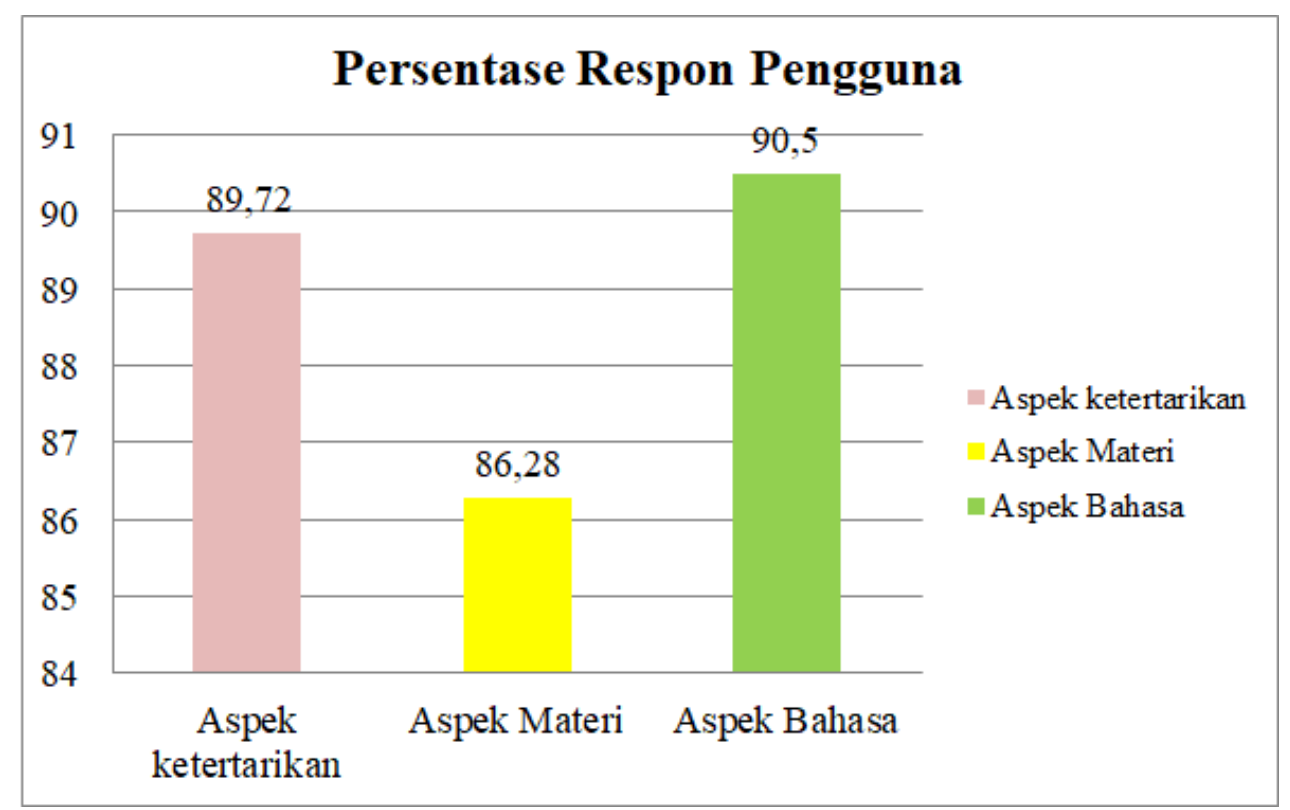

Gambar 5. Persentase Respon Pengguna $e$-modul materi virus

Berdasarkan Gambar 5 di atas secara keseluruhan respon penguna berpredikat sangat baik dengan persentase rata-rata sebesar $88,83 \%$. Hal ini berarti $e$-book alatalat optik yang dikembangkan menarik bagi pengguna dan dapat memotivasi pengguna untuk membaca dan memahami konsep fisika yang diajarkan. Hal ini sejalan dengan penelitian Seruni (2019) yang mengatakan bahwa media yang dianggap efektif dan efisien untuk digunakan belajar mandiri adalah modul elektronik. Hasil Ferdianto dkk. (2019) yang mengatakan bahwa terdapat peningkatan kemampuan matematika peserta didik dengan menggunakan media pembelajaran 3D Pageflip Professional secara signifikan lebih baik daripadaPeserta didik yang memperoleh pembelajaran biasa, dengan rata-rata pre-test 25,59 meningkat dari rata-rata post-test hasil 58.66. Nilai rata-rata $\mathrm{N}$-Gain 0,43 dengan kategori sedang.

\section{KESIMPULAN DAN SARAN}

\section{Kesimpulan}

Berdasarkan penelitian yang dilakukan maka dapat disimpulkan sebagai berikut:

1. $e$-modul materi virus yang dikembangkan layak digunakan dengan revisi dengan presentase rata-rata yang diberikan oleh validator sebesar $80,43 \%$.

2. Keseluruhan peserta didik memberikan respon sangat baik dengan presentase ratarata sebesar $88,83 \%$ terhadap $e$-modul materi virus yang dikembangkan dapat mendukung pembelajaran secara daring.

\section{Saran}

Adapun saran dalam pengembangan $e$-modul ini adalah:

a. Bagi semua pihak yang ingin mengembangkan media ini lebih lanjut, dapat menambahkan materi-materi lain, sehingga produk yang dihasilkan lebih komprehensi dengan menyesuaikan dengan standar kompetensi, kompetensi dasar, 
indikator, dan kebutuhan peserta didik yang dapat berubah sesuai dengan perkembangan pada kurikulum yang berlaku kedepannya pada umumnya, dan perubahan perkembangan pada dunia pendidikan.

b. Bagi peneliti, pada penelitian selanjutnya diharapkan dapat melakukan uji keefektifan media e-book alat-alat optikguna mengetahui pengaruh penggunaan media yang sedang dikembangkan

\section{DAFTAR RUJUKAN}

Alfiah, R. (2020). Strategi guru dalam pembelajaran pai pada masa pandemi covid 19 di SMPN 2 Katingan Hilir (Doctoral dissertation, IAIN Palangka Raya).

Ferdianto, F., \& Nurulfatwa, D. (2019). 3D Page Flip Professional: Enhance of Representation Mathematical Ability on Linear Equation in One Variable. Journal of Physics: Conference Series, 1188(1), 012043.

Handarini, O. I., \& Wulandari, S. S. (2020). Pembelajaran Daring Sebagai Upaya Study From Home (SFH) Selama Pandemi Covid 19. Jurnal Pendidikan Administrasi Perkantoran (JPAP), 8(3), 496-503.

Nurdyansyah, N. (2018). Pengembangan Bahan Ajar Modul Ilmu Pengetahuan Alambagi Siswa Kelas Iv Sekolah Dasar. Universitas Muhammadiyah Sidoarjo.

Prihatiningtyas, S., \& Sholihah, F. N. (2020). Project Based Learning E-Module to Teach Straight-Motion Material for Prospective Physics Teachers. Jurnal Pendidikan Fisika, 8(3), 223-234.

Sadikin, A., Hamidah, A., Pinang, K., Jl, M., Ma, J., Km, B., Indah, M., Jaluko, K., Kode, K. M., \& Indonesia, P. (2020). Pembelajaran Daring di Tengah Wabah Covid-19 (Online Learning in the Middle of the Covid-19 Pandemic). BIODIK: Jurnal Ilmiah Pendidikan Biologi, 6(1), 214-224.

Santosa, T. A., Lufri, L., \& Zulyusri, Z. (2020). Problematika Dalam Pembelajaran Berbasis Virtual Learning Environment (VLE) Terhadap Siswa dan Guru SMA/MA Pada Materi Biologi Di Masa COVID-19. Journal on Education, 3(01), 93-103.

Seruni, R., Munawaroh, S., Kurniadewi, F., \& Nurjayadi, M. (2019). Pengembangan modul elektronik (e-module) biokimia pada materi metabolisme lipid menggunakan Flip PDF Professional. Jurnal Tadris Kimiya, 4(1), 48-56.

Solihudin, T., 2018. Pengembangan E-Modul Berbasis Web Untuk Meningkatkan Pencapaian Kompetensi Pengetahuan Fisika Pada Materi Listrik Statis Dan Dinamis SMA. Jurnal Wahana Pendidikan Fisika, September, 3(2), pp. 51-61.

Sutriyani, W. (2020). Studi Pengaruh Daring Learning Terhadap Minat Dan Hasil Belajar Matematika Mahasiswa Pgsd Era Pandemi Covid-19. Tunas Nusantara, 2(1).

Wulandari, K. (2020). Pengembangan E-modul Fisika Berbasis Karakter Dengan Pendekatan Saintifik. Exact Papers in Compilation (EPiC), 2(03), 299-306.

Kompasiana. 2020. Pembelajaran daring efektif? .https://www.kompasiana.com/arditasyalwa/5e7ba8d6097f36116506b8a2/ pembelajaran-daringefektif. diakses pada 8 April 2021. 